\title{
Large-scale landscape composition and capercaillie (Tetrao urogallus) density in Finland
}

\author{
Janne Miettinen ${ }^{1,3, *}$, Pekka Helle ${ }^{1}$, Ari Nikula ${ }^{2} \&$ Pekka Niemelä $^{3}$ \\ 1) Finnish Game and Fisheries Research Institute, Oulu Game and Fisheries Research, Tutkijantie $2 E$, \\ Fl-90570 Oulu, Finland ( ${ }^{*}$ e-mail: janne.miettinen@rktl.fi) \\ 2) Rovaniemi Research Unit, Finnish Forest Research Institute, P.O. Box 16, Fl-96301 Rovaniemi, \\ Finland \\ 3) Faculty of Forest Sciences, University of Joensuu, P.O. Box 111, Fl-80101 Joensuu, Finland
}

Received 14 June 2007, revised version received 18 Jan. 2007, accepted 18 Jan. 2008

Miettinen, J., Helle, P., Nikula, A. \& Niemelä, P. 2008: Large-scale landscape composition and capercaillie (Tetrao urogallus) density in Finland. - Ann. Zool. Fennici 45: 161-173.

We studied the relationship between landscape composition and capercaillie density in $50 \mathrm{~km} \times 50 \mathrm{~km}$ grids in Finland, where modern forestry started in the 1950s and most of the forests are in commercial use. Capercaillie density was positively associated with the young thinning stand proportion throughout the country, but unlike in numerous older studies, it wasn't positively associated with the mature stand proportion in any part of the country. In central Finland this relationship was even negative. In central and southern Finland capercaillie density was associated positively with the forest land proportion, and negatively with the open area proportion. Results suggest that the overall amount of the forest cover is important for the capercaillie, and that clear-cut areas in the 1950s and 1960s, known as 'large age classes', have developed as suitable for them. A new aspect based on results is the potential reduction in the mature forest quality as capercaillie habitats.

\section{Introduction}

The capercaillie Tetrao urogallus is a large tetraonid bird belonging to the Siberian faunal type (Voous 1960). The distribution of the capercaillie in Finland covers practically the entire country. The original distribution correlates with that of Scots pine (Pinus sylvestris), the main food source for the capercaillie in winter. The only areas where the capercaillie is not found are in the treeless north, in a part of the Baltic Sea archipelago, and in the most densely populated southwestern Finland (Väisänen et al. 1998). Declining densities have been reported throughout most of the species' distribution during the past few decades (e.g. Wegge 1979, Lindén \& Rajala 1981, Hjorth 1994, Beshkarev et al. 1995, Catt et al. 1998, Storch 2000, Helle et al. 2003). The reasons most commonly put forward for the decline are unfavourable changes in the forest structure, bigger predator populations and, possibly, excessive hunting (Helle \& Helle 1991, Storch 2000). Changes in both forest stand and landscape scales caused by forestry are probably among the major factors having a negative effect on the species in Fennoscandia. Predation pressure on grouse nests and broods is also thought to be strongest in landscapes characterized by forest fragmentation associated with modern forestry (Sjöberg 1996, Storaas et al. 1999) or 
agriculture (Kurki et al. 2000). The capercaillie, which is a species with a large home range, has been studied in the context of landscape ecology (e.g. Rolstad \& Wegge 1989), and there is evidence that the capercaillie may have an umbrella species or indicator species characteristics, i.e. a vital capercaillie population would indicate the well-being of many other forest dwelling species (e.g. Suter et al. 2002, Pakkala et al. 2003).

In Finland, forestry, which has been considered the main reason for the loss and degradation of capercaillie habitats, changed extensively during the 20th century. Intensive forest management with clear-cuts started in the 1950 s, while selective cuttings based on a minimum diameter had been used earlier (Leikola 1984). Forests, in northern Finland in particular, were extensively clear-cut after World War II. Now the forests in these former clear-cut areas are growing strongly. Since the middle of the 1970s, the annual proportion of clear-cuts has been constantly about $0.85 \%$ of the forest land area (Finnish Forest Research Institute 2005), but larger areas were clear-cut in the 1950s and the 1960s. These 'large age-classes' in Finnish forests are gradually returning as potential habitats for forest flora and fauna due to growth. A slightly increasing proportion of forested areas (i.e. closed canopy) was also detected in southern Finland from the 1970s to the 1990s (Löfman \& Kouki 2001). With regard to the capercaillie, it has been estimated that this recovery exceeds the loss of areas due to clear-cuts from the beginning of the 1980s (Rolstad \& Andersen 2003).

In this work we study the relationship between landscape composition and capercaillie density in different parts of Finland on a large scale, with a study unit size of $2500 \mathrm{~km}^{2}$, using 12 year-average capercaillie density and 10 landscape classes. Most of the studies carried out on the habitat requirements of the capercaillie have been made on the scale of an individual capercaillie or lekking population covering tens to thousands of hectares (e.g. Rolstad \& Wegge 1989, Helle et al. 1990, Helle et al. 1994, Storch 1997, Miettinen et al. 2005), and our results will be compared with those. Specifically, we test the hypothesis whether the capercaillie is a species suited to mature forests (see e.g. Klaus et al. 1989), or more abundant, for example, in areas characterized by middle-aged forests (Seiskari 1962).

\section{Material and methods}

\section{Study area, capercaillie data and landscape data}

Finland lies between $60-70^{\circ} \mathrm{N}$ and it extends from the hemiboreal zone to the arctic-alpine zone (Ahti et al. 1968). The average cover of forest in Finland is $60.1 \%$ of the total area (ca. $338000 \mathrm{~km}^{2}$ ). Scrubland (mainly pine bog) covers $7.9 \%$ and waste land (mainly open bog) 9.3\% . Agricultural land and human settlements cover $12.7 \%$, and water areas $10.0 \%$ (Finnish Forest Research Institute 2005). The dominant tree species are Scots pine (Pinus sylvestris), Norway spruce (Picea abies) and birch (Betula spp.). Most of the forests are in commercial use and the landscape structure changed considerably during the 20th century due to logging and other human activities.

The capercaillie density data used in this study were derived from the results of wildlife triangle counts (Lindén et al. 1996) carried out in 1989-2000: density (ind. $\mathrm{km}^{-2}$ ) is calculated for a forest land and it includes both adult and juvenile birds. The basic unit of this nationwide monitoring programme is a triangular-shaped transect with a side length of $4 \mathrm{~km}$ (total $12 \mathrm{~km}$ ) permanently marked in the field. Nearly 1000 triangles are studied annually; they are randomly located in forested areas throughout the country. Late summer count data were used in this study and August is a prime time for counting tetraonid birds since the young are still in broods together with their parent(s). Counts are carried out by a three-man chain: the person in the middle walks along the line and the two others at a distance of $20 \mathrm{~m}$ on either side; the width of the census belt is $60 \mathrm{~m}$. For the details and reliability of the method, see Rajala (1974) and Brittas and Karlbom (1990). Volunteers (usually hunters) do the fieldwork and the Finnish Game and Fisheries Research Institute and the Hunters' Central Organization run the programme jointly. Capercaillie density fluctuates strongly from one year to another, and in earlier decades this fluc- 
tuation was cyclical with 5-7-year periods (e.g. Lindén 1989, Lindström 1996), but during this study period the cyclicity largely ceased. For this study, Finland was divided into $50 \mathrm{~km} \times 50 \mathrm{~km}$ grids, giving a total of 150 grid cells (Fig. 1). We used 30 counts during a 12-year study period (1989-2000) in the grid as a minimum, and the final data included 128 grid cells.

The proportion of waters, settlements, agricultural fields, roads and different types of forest were calculated for each grid cell (Table 1). The landscape data were derived from forest statistics reported for each municipality by the national forest inventory (NFI) from 1990-1994 (Tomppo et al. 1998). Since the proportions of different types of forest were reported as a proportion of forest land, all the values were first calculated to correspond to the proportion of the land area of the municipality. If a grid cell included areas in two or more municipalities, then the values of each municipality were weighted by the proportion of the respective municipality area out of the total area of a grid cell. For example, if the area of a grid cell fell in three municipalities, A, $\mathrm{B}$ and $\mathrm{C}$, and the proportions of pine-dominated forests within the municipalities were $60 \%, 30 \%$ and $40 \%$, respectively, and the proportions of the area of a grid cell falling in the municipalities were $0.5,0.25$ and 0.25 , respectively, then the proportion of pine-dominated forests in the grid cell was calculated as $(0.5 \times 0.6)+(0.25 \times 0.3)+$ $(0.25 \times 0.4)=0.3+0.075+0.1=0.475(47 \%)$. Except for the proportion of forests dominated by specific tree species, the estimates produced using this procedure omit the other structural variation of forests within municipalities.

Due to geographical variation and differences in forest-use history, there are gradients in the dominance of certain tree species on the regional scale. Therefore, the proportion of forests dominated by different tree species was interpolated to $1 \mathrm{~km}$ grid cells using pychnophylactic interpolation (Tobler 1979). The idea of this method is to utilize the variation among neighbouring units, in this case municipalities, and to smooth the difference in variable values over the gradient. Smoothing was made by dividing each municipality first into $1-\mathrm{km}$ grid cells and then allocating the original value of a variable to each cell. The algorithm then iteratively changes the

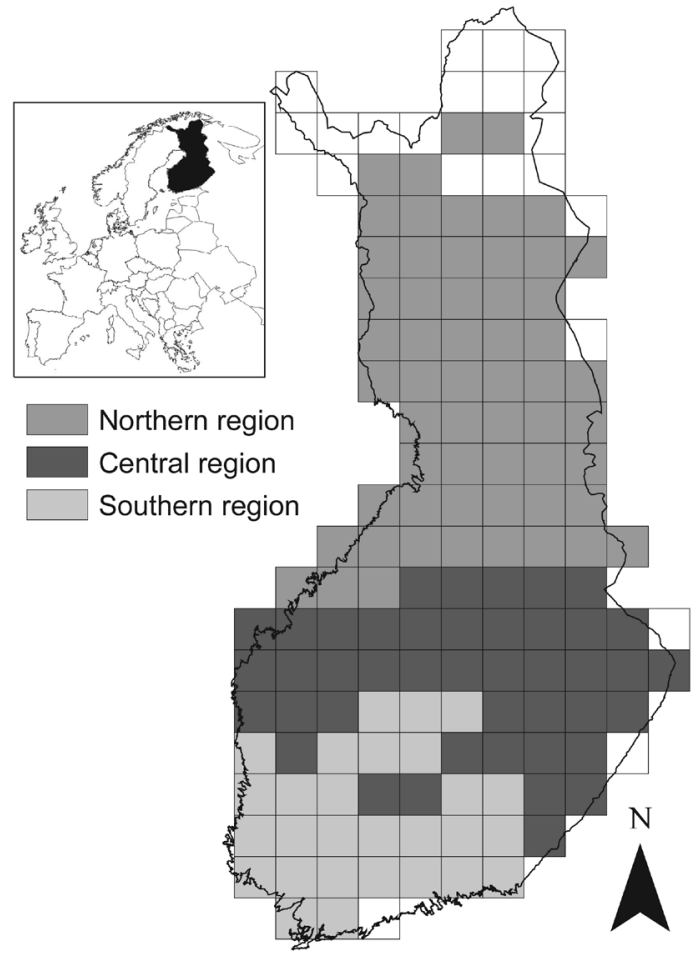

Fig. 1. The study area. Study squares $(50 \mathrm{~km} \times 50 \mathrm{~km})$ were classified into northern $(n=57)$, central $(n=43)$ and southern Finland $(n=28)$ according to the landscape data. Northernmost and some marginal squares were excluded because of insufficient data.

values of individual cells to correspond to a gradient within and among municipalities in such a way that the average of the grid cells within a municipality is the original value of a variable (mass preserving method) (Tobler 1979). The area and proportion of settlements, agricultural fields and waters within the grid cells were calculated from 1:200 000 digitized maps (source: National Land Survey).

\section{Statistical methods}

Aggregating data to zones is a potential source of error if the criterion for aggregating is arbitrary in relation to the study question or data in use (modifiable area unit problem, MAUP, see e.g. Jelinski \& Wu 1996). Therefore, we preferred present-day landscape data in area division rather than e.g. traditional zonations based on vegetation structure (Ahti et al. 1968) or avian geog- 
raphy (Järvinen 1980). We divided Finland into three sub-areas according to landscape data (variables) using the average linkage method (Cody 1974). As a result, northern Finland includes 57 cells, central Finland 43, and southern Finland 28. To further address the scale and zoning problems (MAUP), we compared results with the earlier findings from smaller scales, and studied the data also without sub-area division. We used SPSS (11.5.1) and SAM (Spatial Analysis in Macroecology) (Rangel et al. 2006) softwares in the analyses (SAM is freely available at www. ecoevol.ufg.br/sam). Capercaillie density (Kolmogorov-Smirnov test: in all $Z<0.738$ and $p>$ 0.648 ) and nearly all landscape class proportions were distributed normally in all regions. We used Pearson correlation to describe the relationship between landscape class proportions and capercaillie densities. Because the data are tied to geographical location, spatial autocorrelation may affect the classical tests of correlation coefficients (see e.g. Legendre 1993, Legendre et al. 2002). Therefore Dutilleuls (1993) adjustment was used (whole distance range in 6 classes).
Because of large study units $\left(2500 \mathrm{~km}^{2}\right)$, results may be affected by the broad-scale spatial structure in addition to the quality of individual patches (e.g. Legendre et al. 2002). Therefore the intercorrelation structure between the variables was studied. Due to intercorrelations, we also studied partial correlations between capercaillie density and landscape class proportions to find possible changes in the results when some variables were controlled. The result interpretation here based on the changes in correlation coefficients. In these analyses spatial autocorrelation was not taken into consideration because Dutilleuls adjustment cannot be applied to partial correlation.

\section{Results}

\section{Capercaillie density and landscape class proportions}

The average capercaillie density in August in 1989-2000 was 3.19 ind. $\mathrm{km}^{-2}(\mathrm{SD}=1.26$,

Table 1. Studied landscape classes.

\begin{tabular}{|c|c|c|}
\hline Class & Criteria & Class loadings \\
\hline Mature stand & $\begin{array}{l}\text { Forest land, mean tree diameter } \\
(\mathrm{dbh}) \text { commonly }>23 \mathrm{~cm}\end{array}$ & $\begin{array}{l}\text { Mature or low-productive forest (mostly } \\
\text { due to high age or sparse stocking), age } \\
\text { commonly }>80 \mathrm{yr}\end{array}$ \\
\hline Advanced thinning stand & Forest land, diameter commonly $17-23 \mathrm{~cm}$ & $\begin{array}{l}\text { Middle-aged forest, age commonly } \\
55-80 \mathrm{yr}\end{array}$ \\
\hline Young thinning stand & Forest land, diameter commonly $8-16 \mathrm{~cm}$ & $\begin{array}{l}\text { Middle-aged forest, age commonly } \\
30-55 \mathrm{yr}\end{array}$ \\
\hline Advanced seedling stand & $\begin{array}{l}\text { Forest land, mean tree height } \geq 1.3 \mathrm{~m} \text {, } \\
\text { tree diameter }<8 \mathrm{~cm}\end{array}$ & Young forest, age commonly $15-30 \mathrm{yr}$ \\
\hline Clear-cut & Forest land, height $<1.3 \mathrm{~m}$ & $\begin{array}{l}\text { Young stage: clear-cut, seed-tree stand } \\
\text { or young seedling stand, age commonly } \\
<15 \mathrm{yr}\end{array}$ \\
\hline Naturally open & Average growth $<1 \mathrm{~m}^{3} \mathrm{ha}^{-1} \mathrm{yr}^{-1}$ & $\begin{array}{l}\text { Treeless or sparsely stocked peatlands } \\
\text { or exposed bedrock, lakes, rivers (waste } \\
\text { or scrub land, water) }\end{array}$ \\
\hline Human activity & Average growth $<1 \mathrm{~m}^{3} \mathrm{ha}^{-1} \mathrm{yr}^{-1}$ & $\begin{array}{l}\text { Open areas due to human impact: fields, } \\
\text { settlements, roads, peat production areas }\end{array}$ \\
\hline Forest land & Average growth $>1 \mathrm{~m}^{3} \mathrm{ha}^{-1} \mathrm{yr}^{-1}$ & $\begin{array}{l}\text { Forested areas, varying successional } \\
\text { stages }\end{array}$ \\
\hline Pine-dominated stand & $\begin{array}{l}\text { Forest land, dominant tree species } \\
\text { Scots pine (Pinus sylvestris) }\end{array}$ & Pine forests \\
\hline Non-pine stand & $\begin{array}{l}\text { Forest land, dominant tree species } \\
\text { Norway spruce (Picea abies), } \\
\text { birch (Betula sp.) or other species }\end{array}$ & $\begin{array}{l}\text { Spruce forests or forests dominated by } \\
\text { broadleaf species }\end{array}$ \\
\hline
\end{tabular}


$n=57)$ in the northern region, 3.72 ind. $\mathrm{km}^{-2}$ $(\mathrm{SD}=1.25, n=43)$ in the central region, and 2.38 ind. $\mathrm{km}^{-2}(\mathrm{SD}=0.96, n=28)$ in the southern region (Fig. 2). The capercaillie densities varied between regions (One-way ANOVA: $F$ $=10.614, p<0.001)$, and were significantly different between the southern and central (Bonferroni post-hoc-test: $p<0.001)$ and southern and northern $(p=0.012)$ regions. The average length of wildlife triangle transects counted during the study period was very similar in all the regions, ranging from $1054 \mathrm{~km} /$ grid in the southern to $1072 \mathrm{~km} /$ grid in the northern region.

The proportion of advanced thinning stands increased towards the south, and the proportion of young thinning stands was higher in the northern and central regions than in the southern region, but all the other forest class proportions were relatively similar in all three regions. In all three regions positive correlations between capercaillie density and the young thinning stand proportion were observed (Table 2 and Fig. 3). In the southern region we detected a positive correlation between capercaillie density and the advanced seedling stand proportion and in the central region we detected a negative correlation between capercaillie density and the mature stand proportion.

The average proportion of naturally open areas was highest in the northern and central

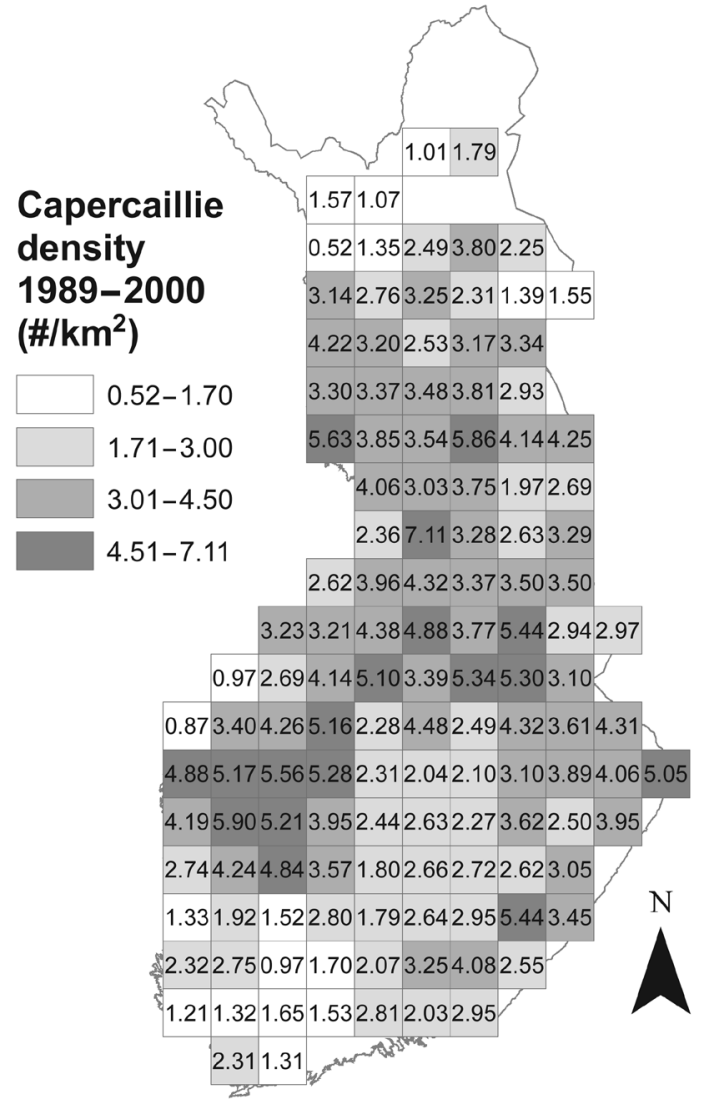

Fig. 2. Average capercaillie densities (ind. $\mathrm{km}^{-2}$ ) during 1989-2000 in Finland within the $50 \mathrm{~km} \times 50 \mathrm{~km}$ squares.

Table 2. Average landscape class proportions (mean, CV) in studied regions. Landscape class proportion and capercaillie density correlations (Pearson, $r_{\mathrm{p}}$ ) in the third column. Statistical significance after Dutilleuls correction: ${ }^{*} p<0.05,{ }^{* *} p<0.01,{ }^{* * *} p<0.001$.

\begin{tabular}{|c|c|c|c|c|c|c|c|c|c|}
\hline \multirow[t]{2}{*}{ Landscape class } & \multicolumn{3}{|c|}{$\begin{array}{l}\text { Northern region } \\
\qquad n=57\end{array}$} & \multicolumn{3}{|c|}{$\begin{array}{l}\text { Central region } \\
\quad n=43\end{array}$} & \multicolumn{3}{|c|}{$\begin{array}{l}\text { Southern region } \\
\qquad n=28\end{array}$} \\
\hline & Mean (\%) & CV (\%) & $r_{\mathrm{p}}$ & Mean (\%) & CV (\%) & $r_{\mathrm{p}}$ & Mean (\%) & CV (\%) & $r_{\mathrm{p}}$ \\
\hline Mature stand & 16.37 & 30.79 & -0.45 & 13.36 & 18.17 & $-0.33^{*}$ & 14.15 & 11.57 & 0.33 \\
\hline Adv. thinning stand & 8.38 & 40.65 & 0.19 & 14.14 & 15.71 & -0.09 & 16.38 & 11.78 & 0.26 \\
\hline Young thinning stand & 23.52 & 25.68 & $0.58^{*}$ & 24.03 & 25.95 & $0.49^{\star *}$ & 19.52 & 24.90 & $0.70^{\star * *}$ \\
\hline Adv. seedling stand & 10.05 & 24.46 & 0.20 & 10.49 & 16.86 & 0.16 & 8.74 & 15.13 & $0.56^{\star \star}$ \\
\hline Clear-cut & 6.51 & 25.70 & 0.03 & 5.96 & 25.17 & 0.22 & 5.84 & 24.62 & 0.35 \\
\hline Naturally open* & 30.85 & 36.72 & -0.29 & 19.68 & 43.67 & $-0.37^{*}$ & 13.55 & 46.65 & 0.29 \\
\hline Human activity & 4.32 & 140.45 & 0.13 & 12.34 & 62.27 & 0.07 & 21.81 & 54.02 & $-0.64^{\star * *}$ \\
\hline Forest land** & 64.06 & 13.53 & 0.30 & 67.79 & 11.15 & $0.32^{*}$ & 64.28 & 13.06 & $0.67^{* * *}$ \\
\hline Pine stand & 49.21 & 13.92 & 0.29 & 42.31 & 27.44 & $0.66^{\star * *}$ & * 34.65 & 29.23 & $0.69^{* * *}$ \\
\hline Non-pine stand & 14.51 & 30.71 & 0.10 & 24.70 & 32.60 & $-0.64^{* * *}$ & * 29.56 & 20.41 & -0.16 \\
\hline
\end{tabular}

* Naturally open areas $80 \%$ scrub or waste land in northern region, $78 \%$ water in central and southern regions.

** Includes mature stand, advanced thinning stand, young thinning stand, advanced seedling stand and clear-cut. 

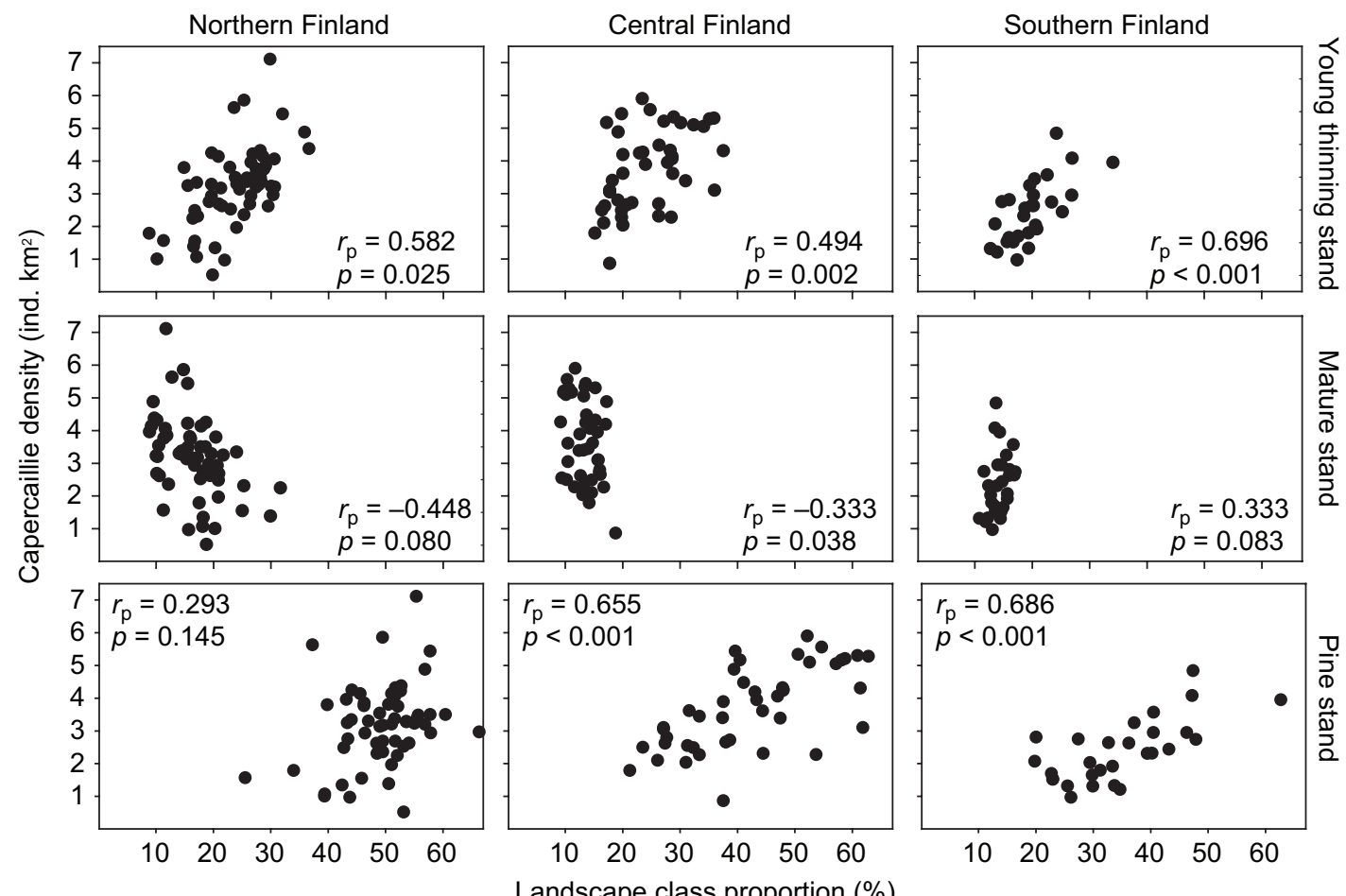

Fig. 3. Capercaillie density and proportions of mature stand, young thinning stand and pine stand in northern, central and southern regions of Finland.

regions, and in the central region a negative correlation between capercaillie density and the naturally open area proportion was observed. The average proportion of human activity was highest in the southern region, and a negative correlation between capercaillie density and the proportion of human activity was observed there.

The average proportion of forest land was $64 \%-68 \%$ in all three regions. In central and southern regions positive correlations between capercaillie density and the forest land proportion were detected. The average proportion of pine stands increased and the proportion of nonpine stands decreased towards the north. In central and southern regions positive correlations between capercaillie density and the pine stand proportion were observed, and in the central region capercaillie density was negatively associated with the non-pine stand proportion.

When the relationship between the landscape class proportions and capercaillie density was studied over the entire study area, the young thinning stand $\left(r_{\mathrm{p}}=0.60, p<0.001\right.$ [after Dutilleul's correction], $n=128$ ), advanced seedling stand $\left(r_{\mathrm{p}}=0.31, p=0.018\right)$, forest land $\left(r_{\mathrm{p}}=0.39\right.$, $p=0.003)$ and pine stand $\left(r_{\mathrm{p}}=0.50, p=0.001\right)$ proportions were positively and the mature stand $\left(r_{\mathrm{p}}=-0.32, p=0.022\right)$ proportion was negatively correlated with capercaillie density.

\section{Landscape class intercorrelations}

In the northern region, negative correlations were observed between the mature stand and advanced thinning stand, young thinning stand, and human activity proportions (Table 3 ). On the other hand, positive correlations were detected between the mature stand and clear-cut and naturally open area proportions. Advanced thinning stand, young thinning stand and human activity proportions were positively correlated in the northern region. All three of those were also negatively associated with naturally open areas. In the northern region the pine stand proportion was positively associated with the young thinning stand, advanced seedling stand and clearcut proportions. 
In the central region the intercorrelation structure differed from that in the northern region. Both mature stand and advanced thinning stand proportions were positively associated with the non-pine stand proportion, whereas young thinning stands were negatively associated with the non-pine stand proportion. Negative correlations were observed also between the advanced thinning stand and young thinning stand and pine stand proportions. Also in the central region the pine stand proportion was positively associated with the young thinning stand, advanced seedling stand and clear-cut proportions.

In the southern region mature forests were positively correlated with the advanced seedling stand, clear-cut and non-pine stand proportions. The advanced thinning stand, young thinning stand and advanced seedling stand proportions were positively associated with the pine stand proportion. In the southern region the proportion of human activity was negatively associated with all five forest development classes.

\section{Partial correlations}

In the northern region the correlation coefficient between the mature stand proportion and capercaillie density was -0.11 when the young thinning stand proportion was controlled (Table 4). However, the correlation coefficient between the mature stand proportion and capercaillie density did not increase considerably from the original values $(\mathrm{N}:-0.45, \mathrm{C}:-0.33$ and $\mathrm{S}: 0.33$, see Table 2) when the pine proportion, young thinning stand proportion or some other variables were controlled.

When the pine stand proportion was controlled, the clearest changes were detected in the central and southern regions. In the cen-

Table 3. Correlation (Pearson) between landscape class proportions in northern (N: $n=57)$, central (C: $n=43)$ and southern region (S: $n=28)$. Statistical significance: ${ }^{*} p<0.05,{ }^{* *} p<0.01,{ }^{\star * *} p<0.001$.

\begin{tabular}{|c|c|c|c|c|c|c|c|c|c|c|}
\hline & & $\begin{array}{l}\text { Mature } \\
\text { stand }\end{array}$ & $\begin{array}{l}\text { Adv. } \\
\text { thinning } \\
\text { stand }\end{array}$ & $\begin{array}{l}\text { Young } \\
\text { thinning } \\
\text { stand }\end{array}$ & $\begin{array}{l}\text { Adv. } \\
\text { seedling } \\
\text { stand }\end{array}$ & Clear-cut & $\begin{array}{l}\text { Naturally } \\
\text { open }\end{array}$ & $\begin{array}{l}\text { Human } \\
\text { activity }\end{array}$ & $\begin{array}{l}\text { Pine } \mathrm{N} \\
\text { stand }\end{array}$ & $\begin{array}{l}\text { Non-pine } \\
\text { stand }\end{array}$ \\
\hline Mature stand & $\begin{array}{l}N \\
C \\
S\end{array}$ & 1.00 & & & & & & & & \\
\hline $\begin{array}{l}\text { Adv. thinning } \\
\text { stand }\end{array}$ & $\begin{array}{l}N \\
C \\
S\end{array}$ & $\begin{array}{l}-0.66^{\star \star \star} \\
0.19 \\
0.13\end{array}$ & 1.00 & & & & & & & \\
\hline $\begin{array}{l}\text { Young thinning } \\
\text { stand }\end{array}$ & $\begin{array}{l}N \\
C \\
S\end{array}$ & $\begin{array}{l}-0.66^{\star \star *} \\
-0.15 \\
0.26\end{array}$ & $\begin{array}{l}0.62^{\star \star *} \\
-0.61^{\star \star \star} \\
0.39^{\star}\end{array}$ & 1.00 & & & & & & \\
\hline $\begin{array}{l}\text { Adv. seedling } \\
\text { stand }\end{array}$ & $\begin{array}{l}N \\
C \\
S\end{array}$ & $\begin{array}{l}0.05 \\
0.28 \\
\mathbf{0 . 5 2} \text { ** }\end{array}$ & $\begin{array}{c}-0.02 \\
-0.25 \\
0.37^{\star}\end{array}$ & $\begin{array}{l}0.38^{\star \star} \\
0.53^{\star \star \star} \\
0.70^{\star \star \star}\end{array}$ & 1.00 & & & & & \\
\hline Clear-cut & $\begin{array}{l}N \\
C \\
S\end{array}$ & $\begin{array}{l}0.42^{\star \star \star} \\
0.06 \\
0.40^{\star}\end{array}$ & $\begin{array}{c}-0.31^{\star *} \\
-0.20 \\
0.16\end{array}$ & $\begin{array}{l}0.06 \\
0.58^{\star \star *} \\
0.57^{\star \star}\end{array}$ & $\begin{array}{l}0.71^{\star \star \star} \\
0.51^{\star *} \\
0.64^{\star \star *}\end{array}$ & 1.00 & & & & \\
\hline Naturally open & $\begin{array}{l}N \\
C \\
S\end{array}$ & $\begin{array}{c}0.35^{\star *} \\
-0.26 \\
0.38^{\star}\end{array}$ & $\begin{array}{c}-0.74^{\star * *} \\
-0.13 \\
0.23\end{array}$ & $\begin{array}{c}-0.75^{\star \star *} \\
-0.31^{*} \\
0.14\end{array}$ & $\begin{array}{c}-0.54^{\star \star *} \\
-0.62^{\star \star \star} \\
0.28\end{array}$ & $\begin{array}{c}-0.27^{*} \\
-0.28 \\
0.00\end{array}$ & 1.00 & & & \\
\hline $\begin{array}{l}\text { Human } \\
\text { activity }\end{array}$ & $\begin{array}{l}N \\
C \\
S\end{array}$ & $\begin{array}{l}-0.59^{\star * *} \\
-0.04 \\
-0.58^{\star *}\end{array}$ & $\begin{array}{l}0.84^{\star \star \star} \\
0.39^{\star} \\
-0.53^{\star \star}\end{array}$ & $\begin{array}{c}0.42^{\star \star} \\
-0.47^{\star *} \\
-0.73^{\star \star \star}\end{array}$ & $\begin{array}{l}-0.01 \\
-0.08 \\
-0.76^{\text {***}}\end{array}$ & $\begin{array}{l}-0.30^{\star \star} \\
-0.43^{\star *} \\
-0.51^{\star \star}\end{array}$ & $\begin{array}{l}-0.71^{\star \star \star} \\
-0.55^{\star \star \star} \\
-0.72^{\star \star \star}\end{array}$ & 1.00 & & \\
\hline Pine stand & $\begin{array}{l}N \\
C \\
S\end{array}$ & $\begin{array}{r}-0.04 \\
-0.21 \\
0.14\end{array}$ & $\begin{array}{c}0.19 \\
-0.42^{\star \star} \\
0.56^{\star *}\end{array}$ & $\begin{array}{l}0.68^{\star \star \star} \\
0.89^{\star \star \star} \\
0.86^{\star \star *}\end{array}$ & $\begin{array}{l}0.65^{\star \star \star} \\
0.55^{\star \star \star} \\
0.53^{\star \star}\end{array}$ & $\begin{array}{l}0.52^{\star * *} \\
0.50^{\star *} \\
0.32\end{array}$ & $\begin{array}{l}-0.60^{\star \star *} \\
-0.52^{\star \star *} \\
0.17\end{array}$ & $\begin{array}{l}-0.03 \\
-0.17 \\
-0.65^{\text {}}\end{array}$ & 1.00 & \\
\hline $\begin{array}{l}\text { Non-pine } \\
\text { stand }\end{array}$ & $\begin{array}{l}N \\
C \\
S\end{array}$ & $\begin{array}{l}-0.08 \\
0.64^{\star * *} \\
0.49^{\star \star}\end{array}$ & $\begin{array}{l}0.52^{\star \star *} \\
0.40^{\star *} \\
-0.09\end{array}$ & $\begin{array}{l}0.36^{\star \star} \\
-0.52^{\star \star \star} \\
-0.15\end{array}$ & $\begin{array}{c}0.35^{\star *} \\
-0.03 \\
0.30\end{array}$ & $\begin{array}{c}0.21 \\
-0.08 \\
\mathbf{0 . 4 2 *}\end{array}$ & $\begin{array}{l}-0.71^{\star * *} \\
0.20 \\
0.11\end{array}$ & $\begin{array}{l}\mathbf{0 . 5 2} \\
-0.10 \\
-0.14\end{array}$ & $\begin{array}{l}0.09 \\
-0.74^{\star \star \star} \\
-0.52^{\star \star}\end{array}$ & * 1.00 \\
\hline
\end{tabular}


tral region correlation coefficient between the advanced thinning stand proportion and capercaillie density increased, but in the cases of the young thinning stand, advanced seedling stand and clear-cut proportion it decreased. In this case the strong positive correlation between the young thinning stand proportion and capercaillie density changed to a negative one.

\section{Discussion}

\section{The importance of overall forest cover}

The capercaillie has traditionally been characterized as a species adapted to the late-successional stages of forest (Klaus et al. 1989, Swenson \& Angelstam 1993, Hjorth 1994). Our results suggest that in managed boreal forests middleaged forests, in terms of single-cohort forest stand management (Oliver \& Larson 1990), are suitable for the capercaillie because a positive relationship between the young thinning stand proportion and capercaillie density was observed throughout Finland. These middle-aged forests also include areas clear-cut in the 1950s and 1960s. In contrast to many earlier results (e.g. Rolstad et al. 1988, Rolstad \& Wegge 1989, Helle et al. 1990, Helle et al. 1994, Storch 1995), the role of mature stands was weak, and the cor- relation with capercaillie density was even negative. The results are in agreement with recent findings from Finland and Norway. In northern Finland the number of males in the lekking site was positively correlated with the proportion of middle-aged forests in lekking site surroundings, but not with the proportion of mature forests (Miettinen et al. 2005). Accordingly, capercaillie lek formation in young (or middle-aged) forests has recently been documented in Norway (Rolstad et al. 2007). Generally the results followed the pattern described by Seiskari (1962) and Swenson and Angelstam (1993), including a wide range of suitable successional stages for the capercaillie. This suggests that the overall amount of forest cover is more important for the capercaillie than any particular successional stage.

The main difference between regions was that capercaillie density was negatively associated with human activity in southern Finland, whereas elsewhere it was negatively correlated with other characteristics of landscapes (water, waste land, scrubland, non-pine stands). The proportion of naturally open areas is temporally quite constant, but, for example, in the south-coast area the proportion of human activity increased from $29 \%$ to $36 \%$ from the 1970 s to the 1990s (Finnish Forest Research Institute 1976, 2005). Due to this process large areas may

Table 4. Partial correlation coefficients between landscape class proportion and capercaillie density in three different regions of Finland when some of the variables are controlled. Statistical significance: ${ }^{*} p<0.05,{ }^{* *} p<0.01,{ }^{* * *}$ $p<0.001$.

\begin{tabular}{|c|c|c|c|c|c|c|c|c|c|}
\hline \multirow[t]{2}{*}{ Landscape class } & \multicolumn{3}{|c|}{ Northern region } & \multicolumn{3}{|c|}{ Central region } & \multicolumn{3}{|c|}{ Southern region } \\
\hline & Pine (\%) & $\begin{array}{l}\text { Young } \\
\text { thinn. } \\
(\%)\end{array}$ & $\begin{array}{l}\text { Young } \\
\text { \& adv. } \\
\text { thinn. } \\
(\%)\end{array}$ & Pine (\%) & $\begin{array}{l}\text { Young } \\
\text { thinn. } \\
(\%)\end{array}$ & $\begin{array}{l}\text { Naturally } \\
\text { open } \\
(\%)\end{array}$ & Pine (\%) & $\begin{array}{l}\text { Young } \\
\text { thinn. } \\
(\%)\end{array}$ & $\begin{array}{c}\text { Human } \\
\text { activity } \\
(\%)\end{array}$ \\
\hline Mature stand & $-0.46^{\star * *}$ & -0.11 & -0.26 & -0.27 & -0.30 & $-0.48^{\star *}$ & 0.33 & 0.22 & -0.05 \\
\hline Adv. thinning stand & 0.14 & $-0.27^{*}$ & - & 0.27 & $0.31^{*}$ & -0.15 & -0.22 & -0.02 & -0.12 \\
\hline Young thinning stand & $0.55^{\star * *}$ & - & - & -0.25 & - & $0.43^{\star *}$ & 0.29 & - & $0.44^{*}$ \\
\hline Adv. seedling stand & 0.02 & -0.03 & -0.14 & $-0.32^{*}$ & -0.14 & -0.10 & 0.33 & 0.15 & 0.16 \\
\hline Clear-cut & -0.15 & -0.01 & -0.15 & -0.17 & -0.10 & 0.13 & 0.19 & -0.08 & 0.04 \\
\hline Naturally open & -0.14 & $0.28^{*}$ & 0.16 & -0.04 & -0.26 & - & 0.24 & 0.27 & -0.31 \\
\hline Human activity & 0.14 & -0.16 & 0.11 & 0.24 & $0.39^{*}$ & -0.18 & -0.34 & -0.26 & - \\
\hline Forest land & 0.10 & -0.23 & $-0.27^{*}$ & $-0.31^{*}$ & -0.13 & 0.15 & 0.30 & 0.13 & 0.30 \\
\hline Pine stand & - & -0.17 & $-0.32^{*}$ & - & $0.54^{* * *}$ & $0.58^{* * *}$ & - & 0.24 & $0.46^{*}$ \\
\hline Non-pine stand & 0.08 & -0.14 & -0.03 & -0.30 & $-0.52^{\star \star *}$ & $-0.62^{\star \star \star}$ & 0.33 & -0.08 & -0.32 \\
\hline
\end{tabular}


have been or will become permanently unable to maintain viable capercaillie populations. Therefore the most southern parts of Finland can be justifiably characterized as an 'area of extinction' for the capercaillie (Lindén et al. 2000).

If all successional stages of forest including closed canopy (young thinning stands, advanced thinning stands and mature stands) were assumed as roughly suitable - according to the estimate that forest suitability for capercaillie may be relatively constant after a certain age (Rolstad \& Wegge 1990) - about $50 \%$ of the study area was suitable area for the capercaillie. Because the proportion is high, suitable patches are likely to form relatively large patches that are located automatically close to each other (see e.g. Andrén 1994), and are thus mostly 'useful' for the capercaillie. Therefore, the habitat proportion probably affects population size more than the patch size or isolation (Fahrig 1997, Jansson \& Andrén 2003) of the capercaillie in Finland. On the other hand, as results concerning mature forests suggest, more coarse-grained aggregation of resources may be beneficial for the species in southernmost Finland, where the proportion of suitable area is low (see e.g. Rolstad \& Wegge 1987).

In the study species density was used to describe the area quality as the capercaillie habitat. It is not necessarily the best indicator of habitat quality because during a short time high densities may occur even in poor habitats (Fretwell \& Lucas 1969, van Horne 1983). But the large scale $\left(2500 \mathrm{~km}^{2}\right.$ study units) and long period (12 years) used in this study make this source of error negligible. In a large scale and long period the basic population level processes - birth, death, immigration and emigration - are the most important processes instead of habitat selection by an individual in smaller scales (e.g. Andrewartha \& Birch 1954). On the one hand, large study scale may mask relationships between landscape structure and capercaillie density due to a small-scale variation in forest composition and in capercaillie density. Also some of the variation is evidently explained by factors not directly related to the landscape structure. These factors include noise (uncontrolled variation in habitat classification and capercaillie density), climatic conditions (variation in winter survival and breeding success) (e.g. Ludwig et al . 2006) as well as hunting and predation pressure (geographical variation in predator assemblages) (Helle \& Helle 1991, Kurki et al. 2000, Storch 2000, Kauhala \& Helle 2002) among others. On the other hand, the large size and the regular shape guarantee the approximate randomness of the wildlife triangles (Lindén et al. 1996), and as there was on average, a high number of counted transect in each grid cell $(>1000 \mathrm{~km}$ in all regions), capercaillie densities within the grid cells are most probably representative.

\section{Mature forests and capercaillie}

Taking into account the previous knowledge about the capercaillie, it was surprising that no positive effect of the mature forest proportion on capercaillie density was found in this study. However, it is already known that the capercaillie does not always prefer old forests; in June and July they were found to use successional stages according to availability (Rolstad et al. 1988), and during winter females and subadult males used middle-aged plantations (Gjerde \& Wegge 1989). On the other hand, in August - when the capercaillie data used in this study were collected - Rolstad et al. (1988) detected the capercaillie to prefer old forest.

The timing of the capercaillie data and landscape data may cause a small bias in the results since the landscape data were from 1990-1994, and capercaillie data from 1989-2000. During the longest possible time gap, 10 years, many mature stands were clear-cut, which may affect the results. The average gap is only about 2 years, however, and therefore the time gap does not explain the observed results. Also the narrow range of the mature stand proportion in central and southern Finland is worth noting because a small variation in the landscape class proportion cannot simply explain the variation in capercaillie density. In the northern region the amount of mature forest increased towards the north $\left({ }^{\circ} \mathrm{N} v s\right.$. mature forest $\%: r_{\mathrm{p}}=0.554, p<0.001$ ), whereas the general productivity decreases towards the north. We tested the effect of latitude in the northern region on the relationship between the mature forest proportion and capercaillie density. 
We used latitude as a controlled variable in a partial correlation, but even this did not change the relationship to positive $\left(r_{\mathrm{p}}=-0.273\right.$, uncorrected $p=0.042$ ). Thus other reasons may have caused the outcome.

The next potential explanation concerns northern Finland in particular and is based on landscape class intercorrelations and spatial structure (e.g. Legendre et al. 2002). First, the 'large age classes' of Finnish forests - areas clear-cut in the 1950s and 1960s - have grown and reached structural features suitable for the capercaillie. In the 1990s they were mostly at the thinning stand stage, and obviously formed large uniform patches where the spatial needs of the capercaillie are likely to be met. For example, a clear-cut of more than 1000 hectares was common in the 1950s and 1960s in northern Finland, and the largest one was about 18000 hectares (Valtanen 1994). Since the 1960s the cutting patterns have changed towards a more fine-grained regime (see also Löfman \& Kouki 2001) and the large mature forest areas that have been cut diminished year by year. Whereas mature forests still formed large patches in the 1970s and 1980s, today they form mostly small patches (e.g. Östlund et al. 1997, Mykrä et al. 2000, Axelsson \& Östlund 2001, Thingstad et al. 2003). In the northern region the mature forest proportion was positively associated with clear-cut and naturally open area proportions. All these classes were negatively associated with the thinning stand proportion. A negative association between mature and middle-aged forests can also be found from results obtained at smaller scale in Sweden (Jansson \& Andrén 2003). These relationships, as well as the increased correlation coefficient between the mature stand proportion and capercaillie density when the young thinning stand proportion was controlled, indicate that mature forests may suffer from the edge effect and isolation (Aune et al. 2005), which may lead to enlarged home ranges and reduced survival of the capercaillie (Wegge \& Rolstad 1986, Storch 1995).

The tree-species composition could also affect the results. This is because during the winter the capercaillie is dependent on pine needles (e.g. Gjerde \& Wegge 1989), and because the mature forests especially in the central region are mostly spruce forests. In the central and southern regions the correlation coefficients changed more than in the northern region when the pine stand proportion was controlled. However, we did not find any variable or group of variables, which would have changed the relationship between the mature stand proportion and capercaillie density to positive.

Another alternative is the inferior quality of the mature forest as a capercaillie habitat. In managed boreal forests ( $>90 \%$ of forests in Finland) the late-successional stages may be degraded by thinnings because of the simplified stand structure (see e.g. Uuttera et al. 1997 , Lilja \& Kuuluvainen 2005). The role of different forest successional stages as capercaillie habitats may also vary due to the variation in the forest stand structure between regions. In central Europe middle-aged forests are mostly too dense for the capercaillie, and mature forests largely represent optimal stand density for the species (Storch 1993). In Finland the forest stand structure in the field layer, where the capercaillie mostly stays during the snow-free season, could be too sparse (open-structured) in even-aged mature forests, especially at poor sites and in northern parts of the country.

\section{Conclusions and prospects}

The results showed that the capercaillie is not strictly an old-forest specialist. The overall forest cover may be more important for the capercaillie than the old age or late successional stage of forests. Middle-aged forests, including the large areas cut in the 1950s and 1960s, known as 'large age classes' have obvious structural characteristics suitable for the capercaillie in the 1990s. In boreal areas, where forestry is major factor modifying forests, the changes are not irreversible because clear-cut areas become young, growing forests relatively soon. An exception is the most southern parts of Finland, where the high proportion of human activity is still increasing. Spatial planning there leading to the aggregation of forest cover would most probably be beneficial for the capercaillie, but the primary concern is whether permanent fragmentation due to agriculture, settlements and roads has exceeded the 
critical threshold for maintaining viable capercaillie populations.

Even though young thinning stands are not necessarily optimal for the capercaillie on the forest stand scale, they commonly form large uniform patches where the spatial needs of the species are likely to be met. Mature forests are known to be important for the capercaillie, as several older studies show, but this study also brought up other aspects. Mature forests may still be high quality capercaillie habitats on the forest stand scale, but the spatial aspects and differences in tree-species composition can overrun it. But the mature forest quality may also be reduced due to thinnings, or they could even naturally possess lower quality as capercaillie habitats than middle-aged forests.

At present, a crucial question in Finnish capercaillie habitat management is: how do thinnings change the quality of forests for the capercaillie? If the quality is not substantially reduced, the capercaillie can be simply and effectively taken into consideration in forest planning by increasing the amount of forest cover. In this case, based on forest age distribution, there would be plenty of suitable areas available for the species during the next few decades in most of Finland. In the other case, there is an urgent need to find ways to improve thinning practice in terms of the capercaillie's needs. If such methods can be found, it would provide a novel tool for environmentally friendly forest management.

\section{Acknowledgements}

We wish to thank volunteer hunters throughout Finland. Their participation in the wildlife triangle counts has made this study possible. Thanks also to Vesa Nivala for his assistance in the data analysis, to Harto Lindén for his valuable comments on the manuscript and to an anonymous referee for the constructive criticism. We are grateful also to the Emil Aaltonen Foundation, whose financial support (to JM) has greatly helped our work.

\section{References}

Ahti, T., Hämet-Ahti, L. \& Jalas, J. 1968: Vegetation zones and their sections in north-western Europe. - Annales Botanici Fennici 5: 169-211.

Andrén, H. 1994: Effects of habitat fragmentation on birds and mammals in landscapes with different proportions of suitable habitat: a review. - Oikos 71: 355-366.

Andrewartha, H. G. \& Birch, L. C. 1954: The distribution and abundance of animals. - University of Chicago Press, Chicago.

Aune, K., Jonsson, B. G. \& Moen, J. 2005: Isolation and edge effects among woodland key habitats in Sweden: Is forest policy promoting fragmentation? - Biological Conservation 124: 89-95.

Axelsson, A.-L. \& Östlund, L. 2001: Retrospective gap analysis in a Swedish boreal forest landscape using historical data. - Forest Ecology and Management 147: 109-122.

Beshkarev, A. B., Blagovidod, A. A., Teplov, V. \& Hjeljord, O. 1995: Populations of capercaillie and hazel grouse in large natural and logged forests in northern Russia. - In: Jenkings, D. (ed.), Proceedings of the 6th International Grouse Symposium, Udine, Italy 1993: 12-18. World Pheasant Association, Lower Basildon, UK.

Brittas, R. \& Karlbom, M. 1990: A field evaluation of the Finnish 3-man chain: a method for estimating forest grouse numbers and habitat use. - Ornis Fennica 67: $18-23$.

Catt, D. C., Baines, D., Picozzi, N., Moss R. \& Summers R. W. 1998: Abundance and distribution of capercaillie Tetrao urogallus in Scotland 1992-1994. - Biological Conservation 85: 257-267.

Cody, M. L. 1974: Competition and the structure of bird communities. - Princeton Univ. Press.

Dutilleul, P. 1993: Modifying the $t$-test for assessing the correlation between two spatial processes. - Biometrics 49: 305-314.

Fahrig, L. 1997: Relative effects of habitat loss and fragmentation on population extinction. - Journal of Wildlife Management 61: 603-610.

Finnish Forest Research Institute 1976: Yearbook of forest statistics 1976.

Finnish Forest Research Institute 2005: Finnish Statistical Yearbook of Forestry 2005.

Fretwell, S. S. \& Lucas, H. L. 1969: On territorial behaviour and other factors influencing habitat distribution in birds. I. Theoretical development. - Acta Biotheoretica 19: $16-36$.

Gjerde, I. \& Wegge, P. 1989: Spacing pattern, habitat use and survival of capercaillie in a fragmented winter habitat. - Ornis Scandinavica 20: 219-225.

Helle, P. \& Helle, T. 1991: How do changes in forest structure explain recent changes in Finnish grouse populations? - Suomen Riista 37: 56-66. [In Finnish with English summary].

Helle, P., Jokimäki, J. \& Lindén, H. 1990: Habitat selection of the male capercaillie in northern Finland: a study based on radiotelemetry. - Suomen Riista 36: 72-81. [In Finnish with English summary].

Helle, P., Helle, T. \& Lindén, H. 1994: Capercaillie (Tetrao urogallus) lekking sites in fragmented Finnish forest landscapes. - Scandinavian Journal of Forest Research 9: 386-396.

Helle, P., Lindén, H., Aarnio, M. \& Timonen, K. 1999: Metso ja metsien käsittely. Tietoa käytännön metsätaloudelle. 
- Metsähallituksen metsätalouden julkaisuja 20: 1-23.

Helle, P., Belkin, V., Bljudnik, L., Danilov, P. I. \& Jakimov, A. 2003: Changes in grouse populations in Finland and Russian Karelia during recent decades. - Suomen Riista 49: 32-43. [In Finnish with English summary].

Hjorth, I. 1994: Tjädern. En skogsfågel. - Skogsstyrelsen, Jönköping.

Jansson, G. \& Andrén, H. 2003: Habitat composition and bird diversity in managed boreal forests. - Scandinavian Journal of Forest Research 18: 225-236.

Jelinski, D. E. \& Wu, J. 1996: The modifiable areal unit problem and implications for landscape ecology. - Landscape Ecology 11: 129-140.

Järvinen, O. 1980: Ecological zoogeography of northern European bird communities. - Ph.D. thesis, Department of Zoology, University of Helsinki.

Kauhala, K. \& Helle, P. 2002: The impact of predator abundance on grouse populations in Finland - a study based on wildlife monitoring counts. - Ornis Fennica 79: $14-25$.

Klaus, S., Andreev, A. V., Bergmann, H.-H., Müller, F., Porkert, J. \& Wiesner, J. 1989: Die Auerhühner. — Die Neue Brehm-Bücherei, Band 86, Westarp Wissenschaften, Madgeburg, Germany.

Kurki, S., Nikula, A., Helle, P. \& Lindén, H. 2000: Landscape fragmentation and forest composition effects on grouse breeding success in boreal forests. - Ecology 81: 1985-1997.

Legendre, P. 1993: Spatial autocorrelation: trouble or new paradigm? - Ecology 74: 1659-1673.

Legendre, P., Dale, M. R. T., Fortin M.-J., Gurevitch, J., Hohn, M. \& Myers, D. 2002: The consequences of spatial structure for the design and analysis of ecological field surveys. - Ecography 25: 601-615.

Ludwig, G. X., Alatalo, R. V., Helle, P., Lindén, H., Lindström, J. \& Siitari, H. 2006: Short- and long-term population dynamical consequences of asymmetric climate change in black grouse. - Proceedings of the Royal Society B 273: 2009-2016.

Leikola, M. 1984: Present-day silviculture. - Silva Fennica 18: 338-342. [In Finnish with English summary].

Lilja, S. \& Kuuluvainen, T. 2005: Structure of old Pinus sylvestris dominated forest stands along a geographic and human impact gradient in mid-boreal Fennoscandia. - Silva Fennica 39: 407-428.

Lindén, H. 1989: Characteristics of tetraonid cycles in Finland. - Finnish Game Research 46: 34-42.

Lindén, H. \& Rajala, P. 1981: Fluctuations and long-term trends in the relative densities of tetraonid populations in Finland, 1964-77. - Finnish Game Research 39: $13-34$.

Lindén, H., Helle, E., Helle, P. \& Wikman, M. 1996: Wildlife triangle scheme in Finland: methods and aims for monitoring wildlife populations. - Finnish Game Research 49: 4-11.

Lindén, H., Danilov, P., Gromtsev, A., Helle, P., Ivanter, E. \& Kurhinen, J. 2000: Large-scale forest corridors to connect the taiga fauna to Fennoscandia. - Wildlife Biology 6: 179-188.

Lindström, J. 1996: Modelling grouse population dynamics.
- Ph.D. thesis, University of Helsinki.

Löfman, S. \& Kouki, J. 2001: Fifty years of landscape transformation in managed forests of southern Finland. - Scandinavian Journal of Forest Research 16: 44-53.

Miettinen, J., Helle, P. \& Nikula, A. 2005: Lek area characteristics of capercaillie (Tetrao urogallus) in eastern Finland as analysed from satellite-based forest inventory data. - Scandinavian Journal of Forest Research 20: 358-369.

Mykrä, S., Kurki, S. \& Nikula, A. 2000: The spacing of mature forest habitat in relation to species-specific scales in managed boreal forests in NE Finland. - Annales Zoologici Fennici 37: 79-91.

Oliver, C. D. \& Larson, B. C. 1990: Forest stand dynamics. - McGraw-Hill, New York.

Östlund, L., Zackrisson, O. \& Axelsson, A.-L. 1997: The history and transformation of a Scandinavian boreal forest landscape since the 19th century. - Canadian Journal of Forest Research 27: 1198-1206.

Pakkala, T., Pellikka, J. \& Linden, H. 2003: Capercaillie Tetrao urogallus - a good candidate for an umbrella species in taiga forests. - Wildlife Biology 9: 309-316.

Rajala, P. 1974: The structure and reproduction of Finnish populations of capercaillie, Tetrao urogallus, and black grouse, Lyrurus tetrix, on the basis of the late summer census data. - Finnish Game Research 35: 1-51.

Rangel, T. F. L. V. B., Diniz-Filho, J. A. F. \& Bini, L. M 2006: Towards an integrated computational tool for spatial analysis in macroecology and biogeography. Global Ecology and Biogeography 15: 321-327.

Rolstad, E. \& Andresen, J. 2003: Storfuglekologi og skogbehandling. - Skogforsk \& Lövenskiold.

Rolstad, J. \& Wegge, P. 1987: Distribution and size of capercaillie leks in relation to old forest fragmentation. - Oecologia 72: 389-394.

Rolstad, J. \& Wegge, P. 1989: Capercaillie populations and modern forestry - a case for landscape ecological studies. - Finnish Game Research 46: 43-52.

Rolstad, J. \& Wegge, P. 1990: Capercaillie habitat: a critical assessment of the role of old forest. - In: Lovel, T. W. I. \& Hudson, P. J. (eds.), Proceedings of the 4th International Grouse Symposium, Lam, West Germany 1989: 235-250. World Pheasant Association, Reading, UK.

Rolstad, J., Rolstad, E. \& Wegge, P. 2007: Capercaillie Tetrao urogallus lek formation in young forest. - Wildlife Biology 13: 59-67.

Rolstad, J., Wegge, P. \& Larsen, B. B. 1988: Spacing and habitat use of capercaillie during summer. - Canadian Journal of Zoology 66: 670-679.

Seiskari, P. 1962: On the winter ecology of the capercaillie, Tetrao urogallus, and the black grouse, Lyrurus tetrix, in Finland. - Papers Game Research 22: 1-119.

Sjöberg, K. 1996: Modern forestry and capercaillie. - In: DeGraaf, R. M. \& Miller, R. I. (eds.), Conservation of faunal diversity in forested landscapes: 111-135. Chapman \& Hall, London.

Storaas, T., Kastdalen, L. \& Wegge, P. 1999: Detection of forest grouse by mammalian predators: A possible explanation for high brood losses in fragmented landscapes. - Wildlife Biology 5: 187-192. 
Storch, I. 1993: Habitat selection by capercaillie in summer and autumn: is bilberry important? - Oecologia 95: 257-265.

Storch, I. 1995: Annual home ranges and spacing patterns of capercaillie in central Europe. - Journal of Wildlife Management 59: 392-400.

Storch, I. 1997: Male territoriality, female range use, and spatial organisation of capercaillie Tetrao urogallus leks. - Wildlife Biology 3: 149-161.

Storch, I. (ed.) 2000: Grouse status survey and conservation action plan 2000-2004. - WPA/BirdLife/SSC Grouse Specialist Group, IUCN, Gland, Switzerland and Cambridge, UK and the World Pheasant Association, Reading, UK.

Suter, W., Graf, R. F. \& Hess, R. 2002: Capercaillie (Tetrao urogallus) and avian biodiversity: testing the umbrellaspecies concept. - Conservation Biology 16: 778-788.

Swenson, J. E. \& Angelstam, P. 1993: Habitat separation by sympatric forest grouse in Fennoscandia in relation to boreal forest succession. - Canadian Journal of Zoology 71: 1303-1310.

Thingstad, P. G., Skjeggedal, T. \& Markhus, G. 2003: Human-induced alteration of two boreal forest landscapes in central Norway, and some possible consequences for avian fauna. - Journal of Nature Conservation 11: 157-170.

Tobler, W. J. 1979: Smooth pycnophylatic interpolation for geographical regions. - Journal of American Statistical Association 74: 519-530.

Tomppo, E., Katila, M., Moilanen, J., Mäkelä, H. \& Peräsaari, J. 1998: Kunnittaiset metsävaratiedot 1990-94. - Folia Forestalia 4B: 619-839.

Uuttera, J., Maltamo, M. \& Hotanen, J.-P. 1997. The structure of forest stands in virgin and managed peatlands: a comparison between Finnish and Russian Karelia. - Forest Ecology and Management: 96: 125-138.

Väisänen, R., Lammi, E. \& Koskimies, P. 1998: Distribution, numbers and population changes of Finnish breeding birds. - Otava, Helsinki. [In Finnish with English summary].

Valtanen, J. 1994: Pohjois-Suomen suuret avohakkuut 194670, yhteiskunnallinen tausta, toteutus ja vaikutukset. - Metsäntutkimuslaitoksen tiedonantoja 533.

van Horne, B. 1983: Density as a misleading indicator of habitat quality. - Journal of Wildlife Management 47: 893-901.

Voous, K. H. 1960: Atlas of European birds. - Nelson, London.

Wegge, P. 1979: Status of capercaillie and black grouse in Norway. - In: Lovel, T. W. I. (ed.), Woodland grouse: 17-26. World Pheasant Association, Suffolk, UK.

Wegge, P. \& Rolstad, J. 1986: Size and spacing of capercaillie leks in relation to social behavior and habitat. - Behavioral Ecology and Sociobiology 19: 401-408. 